\title{
PENGARUH SERTIFIKASI PROFESI TERHADAP KEMAMPUAN GURU BAHASA INDONESIA DALAM MENYUSUN RPP
}

\section{R. Mekar Ismayani*, Aditya Permana}

\author{
Program Studi Pendidikan Bahasa Indonesia IKIP Siliwangi Bandung
}

\begin{abstract}
Abstrak: Penelitian ini dilatarbrlakangi oleh penelitian sebelumnya terkait analisis RPP dan hasil observasi mahasiswa pada mata kuliah Magang II, di lapangan guru masih memiliki kendala dalam menyusun RPP, hal ini terjadi di Kota Cimahi khususnya bagi guru Bahasa Indonesia tingkat SMP. Berdasarkan hal tersebut, focus penelitian ini pada guru bahasa Indonesia tingkat SMP di wilayah Kota Cimahi yang sudah tersertifikasi. Tujuannya untuk mengetahui kemampuan guru dalam menyusun RPP dan pengaruh sertifikasi profesi terhadap kemampuan guru dalam menyusun RPP. Metode penelitian yang digunakan adalah deskriptif dengan teknik penelitian melalui sebaran questioner. Selain hasil angket data penelitian juga berupa RPP yang disusun guru bahasa Indonesia yang tersertifiksi. Hasil menunjukan kemampuan guru dalam menyusun RPP berkatagori baik tetapi dari hasil analisis RPP sebagian besar guru masih kebingungan dalam menyusun RPP terutama komponen orisinalitas, indikator, tujuan pembelajaran, metode, langkah-langkah pembelajaran, dan penilaian. Dengan demikian, sertifikasi profesi berpengaruh terhadap kemampuan guru dalam menyusun RPP namun tidak signifikan.
\end{abstract}

Kata kunci: sertifikasi profesi, rencana pembelajaran, penyusunan RPP

\begin{abstract}
This research is conducted based on the results of the previous Lesson Plan research done by the writer and the result of Lesson Plan observation done by the students of internship II course. The results show that Indonesian Language teachers in Cimahi still have obstacles in preparing the Lesson Plan. Based on the notion, the focus of this research is junior high school Indonesian language teachers in Cimahi that has been certified. The aims of this research are to measure the ability in making Lesson Plan and to analyze the influence of professional certification to the teacher's ability in making Lesson Plan. The research method used is descriptive with research technique through questioner distribution. In addition, the Lesson Plans made by the certified teachers also add as the data. The results of this research show the teachers ability in preparing the Lesson Plan are in good category, yet the results of the analysis show that most of the teachers are still confused in preparing the Lesson Plan, especially on the originality components, indicators, learning objectives, methods, learning steps, and assessment. Hence, the profession certification is not significantly affects the ability of teachers in preparing Lesson Plan.
\end{abstract}

Keywords: professional certification, lesson plan, lesson plan preparation 


\section{PENDAHULUAN}

Undang-Undang guru dan dosen No 14 tahun 2005 pasal 1 ayat 1 menyatakan guru adalah pendidik profesional dengan tugas utama mendidik, mengajar, membimbing, mengarahkan, melatih, menilai, dan mengevaluasi peserta didik pada pendidikan anak usia dini jalur pendidikan formal, pendidikan dasar, dan pendidikan menengah. Selanjutnya, pasal 1 ayat 4 menjelaskan profesional adalah pekerjaan atau kegiatan yang dilakukan oleh seseorang dan menjadi sumber penghasilan kehidupan yang memerlukan keahlian, kemahiran, atau kecakapan yang memenuhi standar mutu atau norma tertentu serta memerlukan pendidikan profesi. Maka, seorang guru tidak hanya bertugas mendidik dan mengajar tetapi harus profesional.

Salah satu cara yang sudah ditempuh pemerintah untuk mewujudkan guru profesional adalah melalui sertifikasi profesi dalam bentuk Pendidikan dan Latihan Profesi Guru (PLPG). Namun, beberapa guru yang memiliki cacat moral melakukan kecurangan-kecurangan untuk dapat terjaring sebagai guru calon tersertifikasi. Kecurangan-kecurangan tersebut misalnya pemalsuan ijazah, kasus ini disampaikan oleh Sultoni (2013) mengungkapkan sebuah data tentang perilaku negatif guru terkait pemalsuan ijazah guna memenuhi syarat kualifikasi mengikuti sertifikasi guru. Dengan demikian, belum tentu seorang guru yang telah tersertifikasi sudah menjadi guru profesioanal jika jalur yang ditempuh dengan cara yang tidak baik.

Dampak dari kecurangan yang dilakukan guru tersebut berakibat pada kompetensi yang dimiliki tidak sesuai dengan persyaratan guru tersertifikasi, misalnya akan terlihat pada kemampuan pedagogiknya. Salah satu komponen yang menyatakan seorang guru memiliki kompetensi pedagogik adalah mampu menyusun RPP. Hasil pengamatan Wikanengsih, Nofiyanti, Mekar Ismayani, dan Indra Permana (2015) selaku salah satu instruktur PLPG mengungkapkan sebagai berikut.

"Berdasarkan data empiris di
lapangan, peneliti sering
menemukan kenyataan bahwa
guru belum sepenuhnya memiliki
kemampuan dalam menyusun
RPP. Salah satu yang peneliti

"Berdasarkan data empiris di lapangan, peneliti sering menemukan kenyataan bahwa guru belum sepenuhnya memiliki RPP. Salah satu yang peneliti 
temukan pada saat Program Latihan Pendidikan Guru (PLPG) yang merupakan salah satu program sertifikasi guru dalam jabatan di mana peneliti sebagai insruktur. Para guru yang berasal dari berbagai kota/kabupaten khususnya di Jawa Barat belum mampu menyusun RPP sesuai dengan peraturan. Alasan yang dikemukakan mereka di antaranya karena RPP yang digunakan di sekolahnya merupakan RPP siap pakai yang telah disusun oleh Musyawarah Guru Mata Pelajaran (MGMP) atau oleh dinas terkait, padahal seharusnya setiap guru harus memiliki kompetensi menyusun RPP."

Di sisi lain, ada sebuah penelitian yang meneliti dampak tunjangan profesi seperti penelitian Darma, dkk. (2010). Hasil penelitian Darma, dkk mengungkapkan adanya dampak tunjangan profesi guru terhadap empat kompetensi dasar yang harus dimiliki oleh seorang guru. Artinya kompetensi pedagodik guru dalam hal ini salah satunya menyusun RPP itu meningkat.

Penelitian Darma, dkk berbanding terbalik dengan hasil penelitian Wikanengsih dan hasil observasi mahasiswa STKIP Siliwangi Bandung angkatan 2013 pada semester IV melalui mata kuliah Magang II tahun 2015. Pada saat itu, kami selaku dosen yang mengampu mata kuliah tersebut meminta mahasiswa untuk melakukan observasi ke sekolah-sekolah. Tujuan observasi tersebut untuk membandingkan RPP yang disusun guru dengan teori penyusunan RPP yang telah mereka dapatkan di kampus. Hampir seluruh hasil laporan observasi mereka mengungkapkan bahwa RPP yang ada di sekolah-sekolah bukan buatan guru melainkan copy paste dan ketika pun membuat sendiri, hal itu hanya sekadar untuk memenuhi kewajiban administrasi dan akreditasi saja, kegunaan RPP itu sendiri tidak dijadikan sebagai hal urgen untuk melaksanakan pembelajaran.

Dari fenomena-fenomena dan hasil penelitian tersebut, menggelitik peneliti untuk melakukan kembali sebuah penelitian apakah memang ada pengaruh sertifikasi profesi dengan kompetensi guru dalam menyusun RPP. Jika penelitian Wikanengsih dkk menitik beratkan pada RPP yang disusun oleh guru, sementara Darma, dkk meneliti dampak tunjangan profesi terhadap empat kompetensi dasar guru, dan penelitian Sultoni menitikberatkan pada peningkatan kompetensi kepribadian guru, maka yang berbeda dengan penelitian ini adalah penelitian ini ingin 
membuktikan apakah guru-guru yang telah tersertifikasi melalui PLPG berpengaruh terhadap peningkatan kualitas kompetensi guru tersebut dalam menyusun RPP.

Dari uraian latar belakang masalah di atas masalah yang dirumuskan dalam penelitian ini meliputi kemampuan guru bahasa Indonesia yang tersertifikasi tingkat SMP di Kota Cimahi dalam menyusun RPP dan pengaruh sertifikasi profesi terhadap kemampuan guru dalam menyusun RPP. Sejalan dengan latar belakang dan rumusan masalah yang telah disusun, penelitian ini bertujuan untuk mengetahui sejauh mana kemampuan guru bahasa Indonesia tingkat SMP di Cimahi khususnya yang telah tersertifikasi serta pengaruh sertifikasi tersebut terhadap kemampuan dalam menyusun RPP.

\section{METODE PENELITIAN}

Berdasarkan rumusan masalah dalam penelitian ini, metode penelitian yang digunakan adalah metode deskriptif kuantitatif. Metode ini dipilih sesuai dengan karakteristiknya yang bertujuan untuk memberikan gambaran, fenomena, yang benar-benar terjadi di lapangan. Hal ini sesuai dengan pendapat Sudjana
(2004:53) bahwa "Metode penelitian deskriptif dengan secara kuantitatif digunakan apabila bertujuan untuk mendeskripsikan atau menjelaskan peristiwa atau suatu kejadian yang terjadi pada saat sekarang dalam bentuk angka-angka yang bermakna.”

Dengan demikian, penelitian ini mendeskripsikan kemampuan guru bahasa Indonesia yang tersertifikasi tingkat SMP di Kota Cimahi dalam menyusun RPP dan menjelaskan pengaruh sertifikasi profesi tersebut dengan kemampuan guru dalam menyusun RPP. Oleh karena itu, hasil penelitian berupa data yang diolah dari angket evaluasi diri dan analisis RPP.

Populasi dalam penelitian ini adalah seluruh guru mata pelajaran Bahasa Indonesia yang tergabung dalam forum MGMP Bahasa Indonesia Tingkat SMP di wilayah Kota Cimahi yang telah tersertifikasi. Mengingat populasi yang cukup besar maka dalam penelitian ini diambil sampel penelitian. Adapun sampel penelitian yang digunakan sebanyak $25 \%$ dari populasi.

Sesuai dengan metode dan rancangan penelitian yang telah ditentukan maka terdapat beberapa langkah atau tahapan penelitian yang dilakukan. 
Tahapan ini dirancang sesuai dengan teori penelitian kuantitatif menurut Sugiyono (2012:30). Tahapan penelitian ini meliputi: a) merumuskan masalah; b) mengkaji teori landasan; c) merumuskan hipotesis; d) mengumpulkan data; e) menganalisis data; dan e) menganalisis data.

Data yang diperlukan untuk menjawab rumusan masalah yakni melalui sebaran kuesioner yang disebarkan kepada responden (guru bahasa Indonesia tingkat SMP di Kota Cimahi yang telah tersertifikasi). Kuesioner yang dijadikan instrumen penelitian meliputi: a) kuesioner kompetensi guru dalam menyusun RPP: b) kuesioner mengenai sertifikasi profesi; dan c) kuesioner mengenai pengaruh sertifikasi profesi terhadap kompetensi guru dalam menyusun RPP.

Sesuai dengan metode yang digunakan, yakni deskriptif kuantitatif, maka teknik analisis data menggunakan teknik analisis regresi ganda dengan taraf signifikan 5\%. Berikut ini kegiatankegiatan yang akan dilakukan dalam tahap analisis data.

a. menetapkan jumlah responden

b. menentukan jumlah butir soal c. menentukan jumlah skor maksimal yang diperoleh dari perkalian antara skor tertinggi, jumlah intern dan jumlah responden

d. menentukan skor minimal yang diperoleh dari perkalian antara skor tertinggi, jumlah intern, dan jumlah responden.

\section{HASIL DAN PEMBAHASAN}

Bagian ini akan menjelaskan hasil penelitian mengenai kemampuan guru bahasa Indonesia tingkat SMP di Cimahi yang telah tersertifikasi dalam menyusun rencana pelaksanaan pembelajaran. Data yang diperoleh berupa hasil sebaran angket penilaian diri dan RPP yang disusun oleh guru tersebut.

Sampel dalam penelitian ini 46 guru bahasa Indonesia yang tersertifikasi dari 67 orang guru bahasa Indonesia yang berasal dari 14 sekolah dari 51 sekolah yang ada di Cimahi meliputi negeri dan swasta. Jika merujuk dari pasal 1 yang dijelaskan terdahulu tentunya 46 orang guru tersebut telah mengajar sesuai dengan bidangnya serta memenuhi jam mengajar yang telah ditentukan. Dengan demikian sertifikasi yang diberikan sedikit banyaknya 
memengaruhi kemampuan guru dalam menyiapkan perencanaan, pelaksanaan, dan evaluasi pengajaran, yaitu kemampuan menyusun RPP.

Berikut deskripsi hasil data penelitian berdasarkan sebaran kuesioner kompetensi guru dalam menyusun RPP yang tersertifikasi dan hasil analisis data RPP produk guru bahasa Indonesia yang tersertifikasi tingkat SMP di Kota Cimahi.

Tabel 1. Hasil Angket Penilaian Diri terhadap Kemampuan Menyusun RPP

\begin{tabular}{|c|c|c|c|}
\hline No. & Pernyataan & $\mathrm{Ya}$ & Tidak \\
\hline A. & Kompetensi dalam Menyusun RPP & & \\
\hline 1. & Anda dapat/mampu menyusun RPP. & $\begin{array}{c}65 \\
(97 \%)\end{array}$ & $\begin{array}{c}2 \\
(3 \%)\end{array}$ \\
\hline 2. & $\begin{array}{l}\text { Anda mengajar dengan mengacu pada RPP yang } \\
\text { disusun oleh sendiri. }\end{array}$ & $\begin{array}{c}65 \\
(97 \%)\end{array}$ & $\begin{array}{c}2 \\
(3 \%)\end{array}$ \\
\hline 3. & $\begin{array}{l}\text { Anda mengajar dengan mengacu pada RPP yang } \\
\text { disusun oleh MGMP. }\end{array}$ & $\begin{array}{c}52 \\
(77,6 \%)\end{array}$ & $\begin{array}{c}15 \\
(22,4 \%)\end{array}$ \\
\hline 4. & $\begin{array}{l}\text { Anda membuat RPP secara bersama-sama (melalui } \\
\text { forum MGMP Sekolah/ kota). }\end{array}$ & $\begin{array}{c}51 \\
(76,11 \%)\end{array}$ & $\begin{array}{c}16 \\
(23,89 \%)\end{array}$ \\
\hline 5. & $\begin{array}{l}\text { Anda menyusun RPP dengan cara copy paste dari } \\
\text { internet. }\end{array}$ & $\begin{array}{c}39 \\
(58,2 \%)\end{array}$ & $\begin{array}{c}28 \\
(41,8 \%)\end{array}$ \\
\hline 6. & $\begin{array}{l}\text { Anda dapat menyusun RPP sesuai dengan tujuan } \\
\text { kompetensi peserta didik. }\end{array}$ & $\begin{array}{c}67 \\
(100 \%)\end{array}$ & $\begin{array}{c}0 \\
(0 \%)\end{array}$ \\
\hline 7. & $\begin{array}{l}\text { RPP yang Anda susun mengacu pada peraturan } \\
\text { pemerintah yang berlaku. }\end{array}$ & $\begin{array}{c}67 \\
(100 \%)\end{array}$ & $\begin{array}{c}0 \\
(0 \%)\end{array}$ \\
\hline 8. & $\begin{array}{l}\text { Anda menetapkan alokasi waktu pembelajaran dalam } \\
\text { RPP sesuai dengan tujuan } \mathrm{SK} / \mathrm{KD} \text { atau KI/KD. }\end{array}$ & $\begin{array}{c}67 \\
(100 \%)\end{array}$ & $\begin{array}{c}0 \\
(0 \%)\end{array}$ \\
\hline 9. & $\begin{array}{l}\text { Dalam menyusun RPP, Anda menguraikan indikator } \\
\text { dengan menggunakan kata kerja operasional. }\end{array}$ & $\begin{array}{c}66 \\
(98,5 \%)\end{array}$ & $\begin{array}{c}1 \\
(5 \%)\end{array}$ \\
\hline 10. & $\begin{array}{l}\text { Dalam menyusun RPP, Anda merumuskan indikator } \\
\text { dengan mengacu kepada pencapaian KD. }\end{array}$ & $\begin{array}{c}66 \\
(98,5 \%)\end{array}$ & $\begin{array}{c}1 \\
(5 \%)\end{array}$ \\
\hline 11. & $\begin{array}{l}\text { Dalam menentukan tujuan pada RPP yang ada susun } \\
\text { sudah memenuhi ABCD (Audience, Behavior, } \\
\text { Condition, Degree). }\end{array}$ & $\begin{array}{c}65 \\
(97 \%)\end{array}$ & $\begin{array}{c}2 \\
(3 \%)\end{array}$ \\
\hline 12. & $\begin{array}{l}\text { Dalam menguraikan materi, Anda selalu } \\
\text { menggunakan sumber yag relevan san sesuai dengan } \\
\text { tujuan } \mathrm{SK} / \mathrm{KD} \text { atau } \mathrm{KI} / \mathrm{KD} \text {. }\end{array}$ & $\begin{array}{c}67 \\
(100 \%)\end{array}$ & $\begin{array}{c}0 \\
(0 \%)\end{array}$ \\
\hline
\end{tabular}




\begin{tabular}{|c|c|c|c|}
\hline 13. & $\begin{array}{l}\text { Anda menetapkan pendekatan, metode, teknik, media, } \\
\text { dan sumber belajar sesuai dengan tujuan } \mathrm{SK} / \mathrm{KD} \text { atau } \\
\mathrm{KI} / \mathrm{KD} \text {. }\end{array}$ & $\begin{array}{c}66 \\
(98,5 \%)\end{array}$ & $\begin{array}{c}1 \\
(5 \%)\end{array}$ \\
\hline 14. & $\begin{array}{l}\text { Alat penilaian/ evaluasi yang Anda susun dalam RPP } \\
\text { sudah mengukur indikator yang harus dicapai oleh } \\
\text { peserta didik. }\end{array}$ & $\begin{array}{c}66 \\
(98,5 \%)\end{array}$ & $\begin{array}{c}1 \\
(5 \%)\end{array}$ \\
\hline B. & Setelah Tersertifikasi & & \\
\hline 1. & $\begin{array}{l}\text { Setelah tersertifikasi, saya lebih serius dalam } \\
\text { menyusun RPP. }\end{array}$ & $\begin{array}{c}45 \\
(97,8 \%)\end{array}$ & $\begin{array}{c}1 \\
(2.2 \%)\end{array}$ \\
\hline 2. & $\begin{array}{l}\text { Setelah tersertifikasi, saya mengikuti forum-forum } \\
\text { pelatihan/musyawarah untuk meningkatkan } \\
\text { keterampilan menyusun RPP. }\end{array}$ & $\begin{array}{c}38 \\
(82,6 \%)\end{array}$ & $\begin{array}{c}8 \\
(17,4 \%)\end{array}$ \\
\hline 3. & $\begin{array}{l}\text { Forum pelatihan/musyawarah menambah wawasan } \\
\text { ihwal menyusun RPP. }\end{array}$ & $\begin{array}{c}43 \\
(93,4 \%)\end{array}$ & $\begin{array}{l}3 \\
(6,6 \%)\end{array}$ \\
\hline 4. & $\begin{array}{l}\text { Forum pelatihan/musyawarah menambah } \\
\text { keterampilan saya dalam menyusun RPP. }\end{array}$ & $\begin{array}{c}45 \\
(97,8 \%)\end{array}$ & $\begin{array}{c}1 \\
(2.2 \%)\end{array}$ \\
\hline 5. & $\begin{array}{l}\text { Sebagaian tunjangan sertifikasi digunakan untuk } \\
\text { pengembangan kemampuan menyusun RPP. }\end{array}$ & $\begin{array}{c}41 \\
(89,1 \%)\end{array}$ & $\begin{array}{c}5 \\
(10,9 \%)\end{array}$ \\
\hline 6. & $\begin{array}{l}\text { Sebagian tunjang sertifikasi digunakan untuk } \\
\text { mengikuti pelatihan/lokalkarya/ seminar menyusun } \\
\text { RPP. }\end{array}$ & $\begin{array}{c}40 \\
(86,9 \%)\end{array}$ & $\begin{array}{c}6 \\
(13,1 \%)\end{array}$ \\
\hline 7. & $\begin{array}{l}\text { Sebagian tunjang sertifikasi digunakan untuk membeli } \\
\text { buku acuan/bahan materi pelajaran. }\end{array}$ & $\begin{array}{c}44 \\
(95,6 \%)\end{array}$ & $\begin{array}{c}2 \\
(4,4 \%)\end{array}$ \\
\hline 8. & $\begin{array}{l}\text { Sebagian tunjang sertifikasi digunakan untuk } \\
\text { menyiapkan metode pembelajaran. }\end{array}$ & $\begin{array}{c}45 \\
(97,8 \%)\end{array}$ & $\begin{array}{c}1 \\
(2.2 \%)\end{array}$ \\
\hline 9. & $\begin{array}{l}\text { Sebagian tunjang sertifikasi digunakan untuk } \\
\text { menyiapkan media pembelajaran. }\end{array}$ & $\begin{array}{c}46 \\
(100 \%)\end{array}$ & $\begin{array}{c}0 \\
(0 \%)\end{array}$ \\
\hline 10. & $\begin{array}{l}\text { Sebagian tunjang sertifikasi digunakan untuk membeli } \\
\text { buku pengembangan penyusunan instrumen penilaian. }\end{array}$ & $\begin{array}{c}41 \\
(89,1 \%)\end{array}$ & $\begin{array}{c}5 \\
(10,9 \%)\end{array}$ \\
\hline 11. & $\begin{array}{l}\text { Anda masih merasa bingung dalam menyusun RPP } \\
\text { walaupun telah tersertifikasi (kemukakan alasan } \\
\text { kebingungan Anda pada kolom keterangan) }\end{array}$ & $\begin{array}{c}44 \\
(95,6 \%)\end{array}$ & $\begin{array}{c}2 \\
(4,4 \%)\end{array}$ \\
\hline
\end{tabular}

Tabel 1 menjelaskan hasil sebaran angket kepada guru bahasa Indonesia dapat dideskripsikan bahwa guru-guru SMP di kota Cimahi memiliki kompetensi yang baik dalam menyusun RPP. Hal tersebut dapat dilihat dari hasil penilaian diri melalui penyebaran angket dengan mengajukan 14 pertanyaan kepada 67 orang guru bahasa Indonesia se-Kota Cimahi, sebagai berikut.

Sebanyak 97\% guru mampu menyusun RPP sedangkan sebanyak 3\% 
guru tidak mampu menyusun RPP. Guru dalam kegiatan mengajar sebanyak 97\% mengacu pada RPP yang disusun sendiri sedangkan $3 \%$ guru tidak.

Selain mengacu pada RPP yang dibuat sendiri, sebanyak $77 \%$ guru juga saat mengajar mengacu/menggunakan RPP yang disusun oleh MGMP sedangkan $22,4 \%$ guru tidak. $76,11 \%$ guru membuat RPP secara bersamasama sedangkan $23,89 \%$ guru tidak membuat RPP bersama-sama. Namun, $58,2 \%$ guru dalam menyusun RPP masih mencopy paste dari internet sedangkan 41,8\% tidak mencopy paste RPP dari internet. $100 \%$ guru dapat menyusun RPP sesuai dengan tujuan kompetensi peserta didik, peraturan pemerintah yang berlaku dan alokasi waktu berdasarkan tujuan SK/KD atau KI/KD. 98,5\% guru menyusun dan merumuskan indikator dengan menggunakan kata kerja operasional serta mengacu pada pencapaian KD. 97\% guru dalam menentukan tujuan pada RPP sudah mengikuti ABCD (Audience, Behavior, Condition, Degree) sedangkan 3\% tidak. Materi pembelajaran yang diuraikan oleh guru dalam RPP 100\% sudah menggunakan sumber yang relevan serta sesuai dengan tujuan $\mathrm{SK} / \mathrm{KD}$ atau
KI/KD. $98,5 \%$ guru sudah menetapkan pendekatan, metode, teknik, media, dan sumber belajar sesuai dengan tujuan $\mathrm{SK} / \mathrm{KD}$ atau $\mathrm{KI} / \mathrm{KD}$ serta menyusun alat penilaian atau evaluasi dengn mengukur indikator capaian peserta didik sedangkan $1 \%$ guru tidak melakukannya.

Kompetensi dalam menyusun RPP yang dimiliki oleh guru setelah tersertifikasi atau memperoleh sertifikasi/ tunjangan untuk mening-katkan kualitas mengajar hendaknya menjadi lebih baik dan memahami penyusunan RPP secara tepat dan benar berdasarkan aturan dan tujuan penca-paian kurikulum yang berlaku.

Dari 67 orang guru bahasa Indonesia baru 46 orang guru yang tersertifikasi. Berdasarkan hasil penilaian diri yang dilakukan melalui angket dengan mengajukan sebelas pertanyaan diketahui kompetensi dalam menyusun RPP pada guru tersebut, sebagai berikut. 97,8\% guru lebih serius dalam menyusun RPP sedangkan 2,2\% tidak. 82,6\% guru yang telah tersertifikasi mengikuti forum-forum/ musyawarah untuk meningkatkan kemampuan atau keterampilan menyusun RPP sedangkan $17,4 \%$ tidak. Forum pelatihan/ musyawarah untuk menambah ihwal 
penyusunan RPP diikuti sebanyak 93,4\% guru tersertifikasi sedangkan $6,6 \%$ tidak. $97,8 \%$ guru mengatakan forum pelatihan/ musyawarah bermanfaat menambah keterampilan dalam menyusun RPP sedangkan 2,2\% tidak. $89,1 \%$ guru menggunakan tunjangan sertifikasi untuk pengembangan kemampuan menyusun RPP sedangkan 10,9\% tidak. $86,9 \%$ guru menggunakan tunjangan sertifikkasi untuk mengikuti pelatihan/ lokakarya/ seminar menyusun RPP sedangkan 13,1\% tidak. 95,6\% guru menggunakan tunjangan sertifikasinya untuk membeli buku acuan/ bahan ajar sedangkan $4,4 \%$ tidak. $97,8 \%$ guru menggunakan tunjangan sertifikasi membeli buku acuan metode pembelajaran sedangkan sebanyak 2,2\% tidak.
$100 \%$ guru menggunakan tunjangan sertifikasi untuk menyiapkan media pembelajaran. $89,1 \%$ guru menggunakan tunjangan sertifikasi untuk membeli buku pengembangan penyusunan instrumen penilaian sedangkan sebanyak 10,9\% tidak. $95,6 \%$ guru masih merasa kebingungan dalam menyusun RPP sedangkan sebanyak 4,4\% tidak. Dengan demikian, dapat diketahui bahwa kompetensi dalam menyusun RPP terhadap guru yang tersertifikasi sudah baik.

Berikut hasil perhitungan angket penilaian diri terhadap kemampuan menyusun RPP untuk pertanyaan bagian B (Setelah tersertifikasi) yang disajikan dalam bentuk diagram.

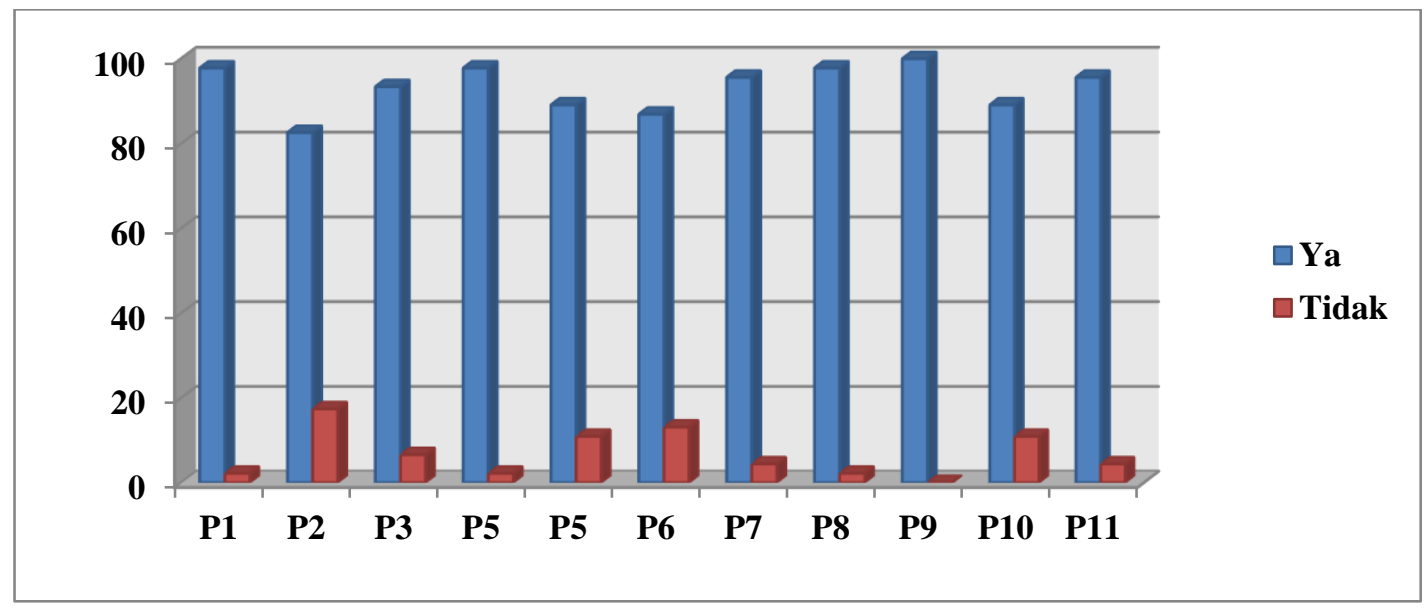

Gambar 1 Hasil Penilaian Diri terhadap Kemampuan Menyusun RPP

Keterangan:

Kode P untuk menyatakan "pertanyaan” dalam angket (contoh: P1 untuk Pertanyaan kesatu, dst.)

R. Mekar Ismayani,dkk. Pengaruh Sertifikasi Profesi.......... 


\section{Analisis RPP}

Selain sebaran questioner berupa penilaian diri di atas, sebagai tambahan data, RPP yang disusun oleh guru yang tersertifikasi juga meruppakan data yang akan dianalisis. Berikut hasil penilaian dari RPP yang disusun oleh guru bahasa Indonesia tingkat SMP yang tersertifikasi di Kota Cimahi.

Perhitungan Skor:

$\frac{\text { Skor Perolehan }}{\text { Skor Ideal }} X 100=\frac{44}{76} X 100=57,8$

Berdasarkan hasil penilaian terhadap RPP yang dibuat oleh guruguru SMP Se-Kota Cimahi diketahui bahwa pada aspek keorisinalitas memeroleh skor 1 dikarenakan belum memiliki ciri khas penyusunan RPP selain itu saat membuat RPP guru-guru masih melihat RPP yang terdapat pada internet bahkan mengcopy paste serta menggunakannya untuk mengajar. Aspek kelengkapan identitas RPP memeroleh skor 1 dikarenakan ada beberapa komponen RPP yang disusun tidak sistematis dan tidak lengkap. Aspek kesesuaian KI dan KD memperoleh skor 2 dikarenakan RPP mencantumkan dengan jelas KI dan KD serta dipasangkan sesuai dengan KI tetapi untuk perumusan indikator dan perumusan tujuan pembelajaran memperoleh skor 1 dikarenakan kata kerja operasinal yang digunakan masih kurang tepat dan tidak memuat $\mathrm{ABCD}$ (Audience, Behavior, Condition, Degree) dalam tujuan pembelajaran. Aspek pengembangan materi dan bahan ajar belum secara jelas memuat aspek konseptual, sistematis, masih ada yang menggunakan referensi yang terlalu lama sehingga memeroleh skor 1. Aspek penggunaan metode dan perumusan langkah-langkah pembelajaran memperoleh skor 1 dikarenakan metode yang digunakan belum bervariasi serta langkah-langkah pembelajaran tidak tergambar jelas. Selanjutnya, pada aspek sumber belajar dan perumusan penilaian memeroleh skor 1 dikarenakan sumber belajar yang digunakan kurang bervariasi, kurang memanfaatkan fasilitas yang ada dan rubik penilaian tidak mencerminkan tujuan atau indikator. Teknis penyusuanan memperoleh skor 1 dikarenakan kurang memerhatikan tanda baca, huruf, kata, kalimat dengan $\mathrm{p}$ tetapi untuk kerapihan serta kebersihan memeroleh skor 2 . 


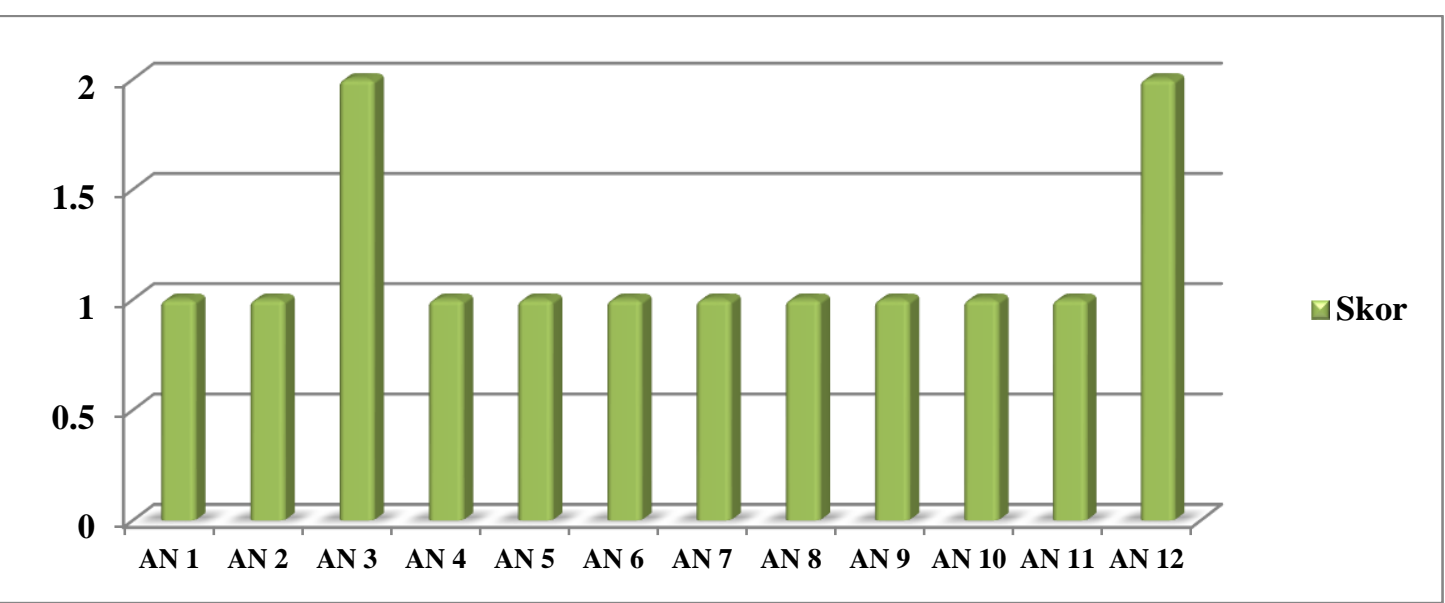

Keterangan:

AN1 : Aspek Penilaian Kesatu

AN2 : Aspek Penilaian Kedua

AN3 : Aspek Penilaian Ketiga

AN4 : Aspek Penilaian Keempat

AN5 : Aspek Penilaian Keempat

AN6 : Aspek Penilaian Keenam

Hasil penilaian terhadap kemampuan menyusun RPP yang disajikan dalam Gambar 2. Dilihat dari hasil perhitungan skor dan analisis setiap aspek penilaian diketahui bahwa kemampuan guru-guru Bahasa Indonesia Se-Kota Cimahi dalam menyusun RPP masih perlu ditingkatkan terutama dalam penjabaran di setiap komponen RPP. Kekeliruan dan kebi-ngungan yang dikemukakan dalam angket penilaian diri terhadap keterampilan menyusun RPP oleh guru-guru yang telah tersertifikasi terlihat dari dua belas aspek penilaian kemampuan menyusun RPP
AN7 : Aspek Penilaian Ketujuh
AN8 : Aspek Penilaian Kedelapan
AN9 : Aspek Penilaian Kesembilan
AN10 : Aspek Penilaian Kesepuluh
AN11 : Aspek Penilaian Kesebelas
AN12 : Aspek Penilaian Kedua Belas

dengan perolehan skor rata-rata sebesar 57,8 .

Dari dua belas aspek penilaian diketahui, guru-guru yang telah tersertifikasi kurang tepat dalam menjabarkan beberapa komponen RPP, yaitu aspek orisinalitas, kelengkapan identitas RPP, perumusan indikator, perumusan tujuan pembelajaran, sumber belajar, metode pembelajaran, langkahlangkah pembelajaran dan perumusan penilaian.

Oleh karena itu, kemampuan guru-guru Bahasa Indonesia se-Kota Cimahi dalam menyusun RPP perlu ditingkatkan dengan memerhatikan penjabaran di setiap komponen RPP. 
Maka, perlu dilakukan pelatihan secara intensif guna meningkatkan kemampuan dan mengatasi kebingungan yang dihadapi guru dalam menyusun RPP yang sesuai dengan aturan serta tujuan kurikulum dalam proses pembelajaran.

\section{KESIMPULAN}

Merujuk pada hasil pengolahan data pene-litian, maka dapat disimpulkan Kemam-puan guru bahasa Indonesia tingkat SMP di Kota Cimahi sudah mampu menyusun RPP hal ini dapat dilihat dari hasil sebaran angket penilaian diri dari 25 pertanyaan yang mengarah pada kemampua menyusun RPP dengan sampel 67 guru, yang menjawab "ya" sebanyak 92,84\% dan $7,156 \%$ menjawab "tidak". Itu artinya semua guru dikatagorikan mampu menyusun RPP dengan baik.Dari hasil pengolahan data angket dan analisis RPP dapat disimpulkan bahwa sertifikasi profesi berpengaruh terhadap kemam- puan guru bahasa Indonesia tingkat SMP di Kota Cimahi dalam menyusun RPP hanya masih ada beberapa guru yang kebingungan dalam merumuskan beberapa komponen RPP. Hal ini dapat dilihat dari hasil analisis angket penilaian diri guru yang tersertifikasi yang menunjukkan $97,8 \%$ guru bahasa Indonesia yang telah tersertifikasi lebih serius dalam menyusun RPP, $89 \%$ guru menggunakan tunjangan sertifikasi untuk pengembangan kemampuan menyusun RPP, 86,9\% guru menggunakan tunjangan sertifikasi untuk mengikuti pelatihan/loka karya/ seminar penyusunan RPP, 95,6\% menggunakan tunjangan sertifikasi untuk membeli buku acuan/bahan ajar, 100\% guru menggunakan tunjangan profesi untuk menyiapkan media pembelajaran, dan $89,1 \%$ menggunakan tunjangan profesi untuk membeli buku instrumen penilaian.

\section{DAFTAR PUSTAKA}

Darma, Y. A., dkk. (2010). Dampak Tunjangan Profesi Guru. Laporan Akhir. Tidak diterbitkan. 
Sudjana, N. (2004). Penelitian dan Penilaian Pendidikan. Bandung: Sinar Baru Algesindo.

Sugiyono. (2012). Metode Penelitian Kuantitatif, Kualitatif, dan R\&D. Bandung: Alfabeta.

Sultoni. (2013). "Pengembangan Model Pengelolaan Pelatihan Motivasional untuk Mendorong Aktualisasi Kompetensi Kepribadian Guru” dalam Jurnal Ilmu Pendidikan, Jilid 19, No. 1 [Juni].

Undang-Undang Republik Indonesia No 14 Tahun 2005 tentang Guru dan Dosen.

Wikanengsih, dkk. (2015). “Analisis Rencana Pelaksanaan Pembelajaran (RPP) Mata Pelajaran Bahasa Indonesia” dalam Jurnal Ilmiah P2M STKIP Siliwangi, Vol.2, No. 1 [Mei]. 